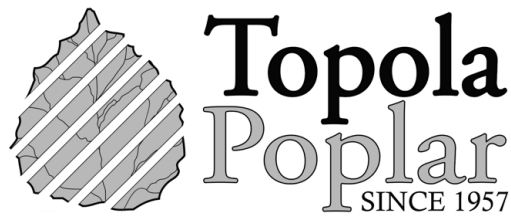

OPEN ACCESS

DOI: $10.5937 /$ topola2108021D

UDC: $633.872: 632.752$

Original scientific paper

\title{
Efficacy of some insecticides for control of oak lace bug (Corythucha arcuata Say)
}

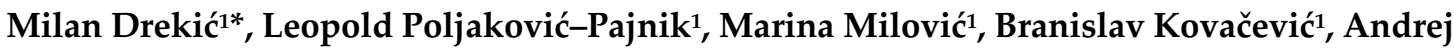 \\ Pilipović ${ }^{1}$, Predrag Pap ${ }^{1}$ \\ 1 University of Novi Sad, Institute of Lowland Forestry and Environment, Novi Sad, Serbia \\ * Corresponding author: Milan Drekić; E-mail: drekicm@uns.ac.rs
}

Received: 10 Sep 2021; Revised: 12 Oct 2021; Accepted: 15 Oct 2021

\begin{abstract}
The oak lace bug (Corythucha arcuata Say) was introduced to Europe from North America in 2000 and was first recorded in Serbia in 2013. It is a very serious oak pest which has harmful effect in both adult and nymph stages of the insect that feeds by sucking the sap on the lower (abaxial) leaf side. As this is a relatively new pest in our country, the possibility of its control by applying insecticides was tested during 2021. The paper presents the test results of three insecticidal active substances: deltamethrin, flonicamid and acetamiprid for the control of oak lace bugs. The insecticide flonicamid did not show sufficient efficacy in the suppression of the oak lace bug, while deltamethrin and acetamiprid have high efficiency for the suppression of the adults and nymphs of the oak lace bug, which recommended them for this purpose.
\end{abstract}

Keywords: Corythuca arcuata, control, insecticides, efficacy.

\section{Introduction}

Harmful organisms introduced from other geographical areas could be a big problem in forest protection. One such organism is the oak lace bug (Corytucha arcuata Say) which was introduced in Serbia from North America. It was observed for the first time in Europe in Italy in 2000 (Bernardinelli and Zandigiacomo, 2000). The range of this pest in Europe then expanded very rapidly and it was found in 2002 in Switzerland (Forster et al. 2005) and Turkey (Matun, 2003). It was found in Bulgaria in 2012 (Dobreva et al. 2013), and in the following year in Croatia and Hungary (Hrašovec et al. 2013; Csoka et al. 2013), as well as in Serbia (Pap et al. 2015). During 2015, it was determined for the first time in Russia (Karpun et al. 2018). In 2016, it was found in Romania (Don et al. 2016) and Slovenia (Jurc and Jurc, 2017). During 2017, it was identified in Bosnia and Herzegovina (Glavendekić et al. 2017), and in Slovakia in 2018 (Zubrik et al. 2018), Moldova (Derjannschi and Mocreac, 2018) and in 2019 in Austria (Sallmannshofer et al. 2019) and Northern Macedonia (Sotirovski et al. 2019). In Serbia, it was found for the first time in the region of Srem in the northwest part of the country (Pap et al, 2015), and it is present today throughout the country.

The oak lace bug has three generations in northern Italy (Bernardinelli, 2001). Damage is caused by adults and larvae that feed by sucking plant sap on the lower (abaxial) side of leaves. First symptom of the attack is the appearance of chlorotic spots on the leaves and black colored particles of excrements. The spots gradually merge, covering the entire leaf, which dries and loses its function. Physiological 
studies indicated that photosynthesis was lowered by $58.84 \%$, transpiration by $21.66 \%$ and stomatal conductivity by $35.71 \%$ compared to non-infested plants (Nikolić et al. 2019). In cases of heavy infestation, the pest can cause defoliation (Mutun et al. 2009). Numerous natural enemies that feed on the oak lace bug have been found in Europe, but none of them significantly reduces its populations (Paulin et al. 2020). Its natural enemies have not been investigated in Serbia. However, results of studies that were carried in Croatia emphasize the potential of entomopathogenic fungi of Beauveria pseudobassiana Rehner et Humber for biological control of this invasive pest (Kovač et al. 2021). Considering the importance of the oak lace bug and the absence of its significant natural enemies, it is necessary to control it on urban greenery, nurseries, and young plants by applying insecticides. So far, there are few studies on the use of insecticides. The insecticides thiacloprid and bifenthrin have been found as effective in controlling the nymphs and adults of the oak lace bug (Drekić et al. 2019), but they are no longer on the market in Serbia. Testing of the possibility of using the insecticides acetamiprid and alpha-cypermethrin from the air to control nymphs was performed in Romania and showed reduction of the population by $91-96 \%$ (Balacenoiu et al. 2021). This paper presents the results of research on the possibility of using three insecticides from different groups for the control of oak lace bugs on pedunculate oak seedlings.

\section{Material and methods}

The efficacy of insecticides in the control of C. arcuata adults and nymphs was tested on Quercus robur L. progeny in the Public Enterprise "Vojvodinašume", Forest Estate "Sremska Mitrovica" (locality Dobreč). One treatment was performed on $11^{\text {th }}$ August 2021. The treatment was performed with a Stihl SR 420 mistblower with a liquid flow of 1.33 1/min and a water consumption of 1000 liters per hectare (Table 1). The person that applied insecticides used adequate personal protective equipment. The experiment was set up according to a completely random block system in three repetitions. The size of the experimental plot was $20 \mathrm{~m}^{2}$. Before the treatment, 10 shoots with nymphs and adults of the oak lace bug were marked on the experimental plot (on 10 plants). During the treatment, the meteorological conditions were adequate for the treatment.

Table 1. Insecticides whose efficacy was tested and applied concentration.

\begin{tabular}{lccc}
\hline $\begin{array}{l}\text { Insecticide } \\
\text { (active ingredient) }\end{array}$ & $\begin{array}{c}\text { Trade } \\
\text { name }\end{array}$ & $\begin{array}{c}\text { Applied } \\
\text { concentration }\end{array}$ & $\begin{array}{c}\text { Applied amount of insecticide } \\
\text { in 10 liters of water }\end{array}$ \\
\hline Deltamethrin & Decis 2.5 EC & $0.05 \%$ & $5 \mathrm{ml}$ \\
Flonicamid & Teppeki 500WG & $0.014 \%$ & $1.4 \mathrm{~g}$ \\
Acetamiprid & Tonus & $0.025 \%$ & $2.5 \mathrm{~g}$ \\
\hline
\end{tabular}

Counting of adults and nymphs on the ten marked shoots of each repetition was performed immediately before treatment, while the recount was performed on day 2 and 10 after the treatment. Efficiency was calculated by the Henderson-Tilton formula (Henderson and Tilton, 1955).

\section{Results and discussion}

Colonization of pedunculate oak shoots before the treatment was moderate counting about 20 nymphs per shoot in control plants (Table 2). The results of the experiment indicate a large decrease in the number of nymphs two days after the treatment with insecticides deltamethrin and acetamiprid. Practically, there were no live nymphs on the shoots after application of these insecticides. When using the insecticide flonicamid 2 days after treatment, the average number of live nymphs per shoot decreased from 9.5 to 2.2. After ten days, the number of live larvae on the shoots treated with insecticides deltamethrin and acetamiprid was very low, while in the treatment with flonicamid average number was around 8 live nymphs per shoot. 
Two days after the treatment, the efficiency of the applied preparations based on the active ingredients deltamethrin and acetamiprid was $100 \%$. Flonicamid had a significantly lower efficacy of $76.4 \%$. An efficacy of more than $99 \%$ was found for the insecticides deltamethrin and acetamiprid ten days after the treatment.

Table 2. Number of nymphs before and after the treatment and insecticide efficacy.

\begin{tabular}{|c|c|c|c|c|c|c|}
\hline \multirow[t]{2}{*}{ Treatment } & \multirow{2}{*}{$\begin{array}{l}\text { Assessment } \\
\text { time }\end{array}$} & \multicolumn{3}{|c|}{$\begin{array}{c}\text { Average number of nymphs } \\
\text { per shoot }\end{array}$} & \multirow[t]{2}{*}{ Mean } & \multirow[t]{2}{*}{ Efficacy (\%) } \\
\hline & & I & II & III & & \\
\hline \multirow[t]{3}{*}{ Deltamethrin } & BT & 21.7 & 16.3 & 19.4 & 19.1 & - \\
\hline & $2 \mathrm{DAT}$ & 0 & 0 & 0 & 0 & 100 \\
\hline & $10 \mathrm{DAT}$ & 0 & 0.2 & 0.1 & 0.1 & 99.4 \\
\hline \multirow[t]{3}{*}{ Flonicamid } & BT & 9.0 & 10.5 & 9.1 & 9.5 & - \\
\hline & $2 \mathrm{DAT}$ & 4.8 & 8.0 & 1.1 & 2.2 & 76.4 \\
\hline & $10 \mathrm{DAT}$ & 2.4 & 16.3 & 5.8 & 8.1 & 4.8 \\
\hline \multirow[t]{3}{*}{ Acetamiprid } & BT & 17.2 & 23.7 & 18.6 & 19.8 & - \\
\hline & $2 \mathrm{DAT}$ & 0 & 0 & 0 & 0 & 100 \\
\hline & $10 \mathrm{DAT}$ & 0.2 & 0 & 0 & 0.1 & 99.4 \\
\hline \multirow[t]{3}{*}{ Control } & BT & 18.1 & 15.7 & 26.6 & 20.1 & - \\
\hline & $2 \mathrm{DAT}$ & 16.7 & 19.2 & 30.3 & 19.7 & - \\
\hline & $10 \mathrm{DAT}$ & 13.5 & 13.8 & 26.6 & 18.0 & - \\
\hline
\end{tabular}

Legend: BT - before treatment; 2 DAT - 2 days after treatment; 10 DAT - 10 days after treatment.

In the suppression of $C$. arcuata nymphs, the insecticide flonicamid showed a weak residual effect and an efficiency of only $4.8 \%$ ten days after the treatment. The good efficacy of the insecticide acetamiprid applied from the air in the suppression of nymphs was indicated by research conducted in Romania (Balacenoiu et al. 2021).

In addition to nymphs, adults cause great damage to oaks by feeding, and therefore it is necessary to suppress them also. The results of testing the effectiveness of insecticides to control adults are shown in Table 3.

Table 3. Number of alive adult before and after treatment and insecticide efficacy.

\begin{tabular}{llllllll}
\hline \multirow{2}{*}{ Treatment } & \multirow{2}{*}{$\begin{array}{c}\text { Assessment } \\
\text { time }\end{array}$} & \multicolumn{4}{c}{$\begin{array}{c}\text { Average number of adults } \\
\text { per shoot }\end{array}$} & \multirow{2}{*}{ Mean } & Efficacy (\%) \\
\cline { 3 - 5 } & & \multicolumn{2}{c}{ I } & \multicolumn{1}{c}{ II } & III & & \\
\hline Deltamethrin & BT & 7.4 & 4.6 & 10.1 & 7.4 & - \\
& 2 DAT & 0 & 1 & 0 & 0.3 & 97.5 \\
& 10 DAT & 0 & 0 & 1.0 & 0.3 & 97.5 \\
\hline Flonicamid & BT & 2.6 & 3.9 & 4.5 & 3.7 & - \\
& 2 DAT & 2.1 & 2.5 & 1.6 & 2.1 & 64.7 \\
& 10 DAT & 19.2 & 16.0 & 20.1 & 18.4 & -25.0 \\
\hline Acetamiprid & BT & 8.0 & 6.7 & 3.9 & 6.2 & - \\
& 2 DAT & 0 & 0 & 0 & 0 & 100 \\
& 10 DAT & 1.0 & 1.3 & 1.8 & 1.4 & 94.3 \\
\hline Control & BT & 5.7 & 5.6 & 2.4 & 4.6 & - \\
& 2 DAT & 4.9 & 9.1 & 8.3 & 7.4 & - \\
& 10 DAT & 20.2 & 19.6 & 15.1 & 18.3 & - \\
\hline
\end{tabular}

Legend: BT - before treatment; 2 DAT - 2 days after treatment; 10 DAT - 10 days after treatment. 
In the control was found an increase in the number of adults, from an average of 4.6 per shoot before the treatment to an average of 18.3 adults per shoot after 10 days, which is the result of mass emergence of adults of the new generation. Two days after the treatment, no adults of oak lace bugs were found on the plants treated with the insecticide acetamipride, while their number was rapidly reduced with the use of deltamethrin. By applying the insecticide flonicamid, the average number of adults on the treated shoots was reduced from 3.7 to 2.1, which presents an insufficient reduction. After 10 days, the number of adults on plants treated with the insecticides deltamethrin and acetamiprid remained low, while in the treatment with flonicamid it increased several times, indicating the absence of residual action.

The efficiency of $100 \%$ was stated with the application of the insecticide acetamiprid on two days after the treatment, and $94.3 \%$ after ten days. Similar effectiveness for controlling adults was achieved with the use of insecticide deltamethrin with an efficiency of $97.5 \%$ both after two and ten days after the treatment. The preparation based on the active ingredient flonicamid did not show sufficient efficacy to control adults. The insecticides deltamethrin and acetamiprid have shown very good efficacy for controlling the adults of $C$. arcuata, and this is of a great practical importance. It is highly recommended that the treatment with the aim of controlling overwintering adults should be done in late April and early May during the supplementary diet, and before laying eggs. By reducing the population of the oak lace bug at that moment, it is possible to avoid significant damage during the rest of the vegetation. The most favorable time for the reduction of the nymph population is the middle of June, when the first-generation nymphs are present massively on the leaves.

Later, during vegetation, there is an overlap of generations and the presence of all developmental stages of oak lace bugs on plants at the same time, which certainly requires multiple application of insecticides and higher costs of control in addition to already caused damage. The use of insecticides against oak lace bugs is justified in nurseries, tree lines, parks and in the protection of oak seedlings in the first years after reforestation. The wide application of insecticides acetamiprid and deltamethrin is restricted due to high toxicity for bees and other insects and mites, while acetamiprid is forbidden in the area of water protection. The application of insecticides in forest complexes on large areas is not environmentally and economically acceptable because they are large pollutants, often non-selective, disturb ecological balance and their application is very expensive. The fact that nymphs and adults oak lace bug are feeding on abaxial leaf side makes difficulties in application of insecticides. An acceptable option for controlling C. arcuata in larger forest complexes is biological control, i.e. use of efficient natural enemies, which should be studied in detail and only then applied.

\section{Conclusions}

The insecticide flonicamid has not shown sufficient efficacy in controlling the adults and nymphs of the oak lace bag. The tested insecticides deltamethrin and acetamiprid have been shown to be highly effective in controlling adults and nymphs of oak lace bug. The best time to control adults is in late April and early May during supplementary feeding, and to control nymphs in mid-June.

\section{Acknowledgement}

This study was financed by the Ministry of Education, Science and Technological Development of the Republic of Serbia (Contract No. 451-03-9/2021-14/200197) and Ministry of Agriculture, Forestry and Water Management of the Republic of Serbia (Contract No. 401-00-58/2020-10).

\section{References}

1. Balacenoiu, F., Netoiu, C., Tomescu, R., Carol Simon, D., Buzatu, A., Toma, D., Catalin Petritan, I. (2021): Chemical control of Corythucha arcuata (Say, 1832), an invasive alien species, in oak forests. Forests 12: 770. doi:https://doi.org/10.3390/f12060770 
2. Bernardinelli, I., Zandigiacomo, P. (2000): Prima segnalazione di Corythucha arcuata (Say) (Heteroptera, Tingidae) in Europa. Informatore Fitopatologico 50: 47-49.

3. Bernardinelli, I. (2001): GIS representation of Corythucha arcuata (Say) distribution in northern Italy. Journal of Forest Science 47: 54-55.

4. Csóka, G., Hirka, A., Somlayi, M. (2013): A tölgy csipkespoloska Corythucha arcuata Say, 1832 Heteroptera, Tingidae) elsŏ észlelése Magyarországon, Növényvédelem, 49(7): 293-296.

5. Derjannschi, V., Mocreac, N. (2018): Tigrul stejarului Corythucha arcuata (Say, 1832) (Heteroptera, Tingidae) - species noua invzivain fauna Republicii Moldova. Buletin Ştiințific. Revistă de Etnogra-fie, Ştiințele Naturii și Muzeologie 28(41): 30-35.

6. Dobreva, M., Simov, N., Georgiev, G., Mirchev, P., Georgieva, M. (2013): First record of Corythucha arcuata (Say) (Heteroptera: Tingidae) on the Balkan Peninsula. Acta Zoologica Bulgarica 3: 409-412.

7. Don, I., Don, C.D., Sasu, L.R., Vidrean, D., Brad, M.L. (2016): Insect pests on the trees and shrubs from the Macea Botanical garden. Studia Universitatis 'Vasile Goldişs' Arad Seria Ştiințe Inginereşti şi Agro-Turism 11(2): 23-28.

8. Drekić, M., Poljaković- Pajnik, L., Pilipović A., Nikolić, N. (2019): Suzbijanje hrastove mrežaste stenice Corythuca arcuata Say. Šumarstvo 3-4: 215-223.

9. Forster, B., Giacolone, I., Moretti, M., Dioli, P., Wermelinger, B. (2005): Die Amerikanishe Eichennetzwanze Corythucha arcuata (Say) (Heteroptera, Tingidae) hat die Sudschweitz erreicht. Mitteilungen der Schweizerischen Entomologischen Gessellschaft Bulletin de la Societe Entomologue Suisse 78: 317-323.

10. Glavendekić, M., Vuković Bojanović, V. (2017): Prvi nalaz hrastove mrežaste stenice Corythucha arcuata (Say) (Hemiptera: Tingidae) u Bosni i Hercegovini i novi nalazi u Srbiji. Book of Abstracts of XI Symposium of Entomologists of Serbia, Goč: 70-71.

11. Henderson, C.F., Tilton E.W. (1955): Tests with acaricides against the brow wheat mite. Journal of Economic Entomology 48: 157-161.

12. Hrašovec, B., Posarić, D., Lukić, I., Pernek, M. (2013): Prvi nalaz hrastove mrežaste stenice Corythucha arcuata u Hrvatskoj. Šumarski list 9-10: 499-503.

13. Jurc, M., Jurc, D. (2017): The first record and the beginning the spread of oak lace bug, Corythucha arcuata (Say, 1832) (Heteroptera: Tingidae) in Slovenia. Šumarski list 9-10: 485-488.

14. Karpun, N.N., Protsenko, V.Y., Borisov, B.A., Shiryaeva, N.V. (2018): A new record of the oak lace bug, Corythucha arcuata (Say, 1832) (Heteroptera: Tingidae), in subtropical zone of black Sea coast of the caucasus with forecast of phytosanitary situation change in the region. Euroasian entomological journal 17(2): 113-119.

15. Kovač, M., Linde, A., Lacković, N., Bollmann, F., Pernek, M. (2021): Natural infestation of entomopathogenic fungus Beauveria pseudobassiana on overwintering Corythucha arcuata (Say) (Hemiptera: Tingidae) and its efficacy under laboratory conditions. Forest Ecology and Management 491(2): 119193. doi:10.1016/j.foreco.2021.119193

16. Mutun, S. (2003): First report of the oak lace bug, Corythucha arcuata (Say, 1832) (Heteroptera, Tingidae) from Bolu, Turkey. Israel Journal of Zoology 49(4): 323-324.

17. Mutun, S., Ceyhan Y., Sözen C. (2009): Invasion by the oak lace bug, Corythucha arcuata (Say) (Heteroptera: Tingidae), in Turkey. Turkish Journal of Zoology 33: 263-268.

18. Nikolić N., Pilipović, A., Drekić, M., Kojić, D., Poljaković-Pajnik, L., Orlović, S., Arsenov, D. (2019): Physiological responses of pedunculate oak (Quercus robur L.) to Corythucha arcuata (Say, 1832) attack. Archives of Biological Sciences 71(1): 167-76.

19. Pap, P., Drekić, M., Poljaković-Pajnik, L., Marković, M., Vasić, V. (2015): Monitoring zdravstvenog stanja šuma na teritoriji Vojvodine u 2015. godini. Topola 195/196: 117-133.

20. Paulin, M., Hirka, A., Béla Eötvös, C., Gáspár, C., Fürjes-Mikó, A., Csóka, G. (2020): Known and predicted impacts of the invasive oak lace bug (Corythucha arcuata) in European oak ecosystems - a review. Folia Oecologica 47 (2): 131-139. 
21. Sotirovski, K., Srebrova, K., Nacheski, S. (2019): First records of oak lace bug Corythucha arcuata (SAY, 1832) (Hemiptera: Tingidae) in North Macedonia, Acta entomologica Slovenica 2: 91-98.

22. Sallmannshofer, M., Ette, S., Hinterstoisser, W., Cech, T.L., Hoch, G., (2019): Erstnachweis der Eichennetzwan-ze, Corythucha arcuata, in Österreich. Forstschutz Aktuell 66: 1-6.

23. Zúbrik, M., Gubka, A., Rell, S., Kunca, A., Vakula, J., Galko, J., Nikolov, Ch., Leontovyč, R., (2019): First record of Corythucha arcuata in Slovakia. Short communication. Plant Protection Science 55: 129-133. 